\title{
Penerapan Teknologi Augmented Reality Pada Pembelajaran Huruf Kaganga Sunda Dengan Metode Marker Tracking
}

\author{
Irwin Supriadi', Amras Mauluddin', Arif Nur Imam \\ 1,2,3 Program Studi Teknik Informatika \\ ${ }^{1,2}$ Universitas Langlangbuana, Jl. Karapitan No.116 Bandung \\ ${ }^{3}$ Sekolah Tinggi Teknologi Bandung, Jl. Soekarno-Hatta No. 378 Bandung \\ Email : irwinshared@gmail.com ${ }^{1}$, amrasmauluddin@gmail.com ${ }^{2}$, \\ nurimam.arif@gmail.com ${ }^{3}$
}

\begin{abstract}
ABSTRAK
Pandemi Covid-19 ini semua kegiatan manusia telah mulai berubah, smartphone menjadi sebuah alat yang sangat berguna dalam kehidupan sehari-hari manusia terutama dalam kegiatan transaksi ekonomi. Tidak terlepas juga dalam dunia pendidikan, model pembelajaran tatap muka secara langsung tergantikan dengan model pembelajaran secara daring (dalam jaringan) memanfaatkan smartphone dan internet. Kendala yang dihadapi adalah beberapa mata pelajaran yang diberikan oleh guru kurang dipahami oleh siswa karena hanya berupa teks atau gambar. Selain itu, dengan cara belajar membaca teks kurang menarik bagi siswa dan menyebabkan siswa menjadi bosan atau jenuh.

Augmented reality adalah salah satu perkembangan teknologi dalam bidang perangkat lunak. Augmented Reality banyak digunakan dalam industri game, pendidikan, maupun kedokteran dikarenakan dapat memodelkan suatu objek dalam bentuk 3 Dimensi yang menyerupai objek sebenarnya. Penelitian ini dimaksudkan untuk mengkombinasikan teknologi augmented reality dalam bidang pendidikan untuk mengurangi kejenuhan siswa dalam pembelajaran.

Metodologi penelitian yang digunakan oleh peneliti untuk menyusun laporan ini adalah metode kualitatif dimana pada metode ini penelitian dilakukan secara sistematis, spesifik, terstruktur dan juga terencana dengan baik dari awal hingga mendapatkan sebuah kesimpulan. Metode pengembangan sistem yang digunakan adalah metode Rappid Application Develepoment (RAD). Rapid Application Development (RAD) merupakan metodologi yang lengkap, dengan 4 fase siklus hidup yang sejajar dengan fase SDLC tradisional

Pembelajaran huruf kaganga sunda dibuat dalam bentuk animasi 3 dimensi yang mengajarkan cara penulisan aksara sunda, sehingga dapat menarik bagi siswa SD. Aplikasi ini juga menggunakan teknologi augmented reality dalam aplikasi android, sehingga siswa SD dapat belajar sambil bermain.
\end{abstract}

Kata Kunci : Augmented Reality, huruf kaganga sunda, pembelajaran, Rapid Application Development, 3 dimensi.

\section{ABSTRACT}

The Covid-19 pandemic has started to change all human activities, smartphones are becoming a very useful tool in people's daily lives, especially in economic transaction activities. It is also inseparable from the world of education, face-to-face learning models are directly replaced by online learning models (online) utilizing smartphones and the internet. The obstacle faced is that some of the subjects given by the teacher are 
not understood by students because they are only in the form of text or pictures. In addition, learning to read text is less attractive to students and causes students to become bored or bored.

Augmented reality is one of the technological developments in the software field. Augmented Reality is widely used in the gaming, education, and medical industries because it can model an object in a 3-dimensional form that resembles the actual object. This research is intended to combine augmented reality technology in education to reduce student boredom in learning.

The research methodology used by researchers to compile this report is a qualitative method wherein this method research is carried out in a systematic, specific, structured, and well-planned manner from the beginning to reach a conclusion. The system development method used is the Rapid Application Development (RAD) method. Rapid Application Development (RAD) is a comprehensive methodology, with 4 lifecycle phases that parallel the traditional SDLC phases

Learning Sundanese kaganga letters is made in the form of 3-dimensional animation which teaches how to write Sundanese characters so that it can be interesting for elementary students. This application also uses augmented reality technology in the android application, so that elementary students can learn while playing.

Keywords: Augmented Reality, Sundanese kaganga letters, learning, Rapid Application Development, 3 dimensions.

\section{PENDAHULUAN}

\subsection{Latar Belakang}

Teknologi merupakan sebuah alat yang digunakan penggunanya untuk mempermudah memenuhi kebutuhan masing-masing orang. Perkembangan teknologi informasi yang semakin pesat sekarang ini membuat pekerjaan manusia menjadi semakin mudah. Salah satu perkembangan teknologi komunikasi dan informasi yang paling cepat adalah telepon pintar (smartphone). Dengan adanya smartphone, manusia dapat mengerjakan segala sesuatu hanya dari genggaman tangan selama smartphone tersebut terkoneksi dengan internet.

Dengan adanya pandemi Covid-19 ini semua kegiatan manusia telah mulai berubah, smartphone menjadi sebuah alat yang sangat berguna dalam kehidupan sehari-hari manusia terutama dalam kegiatan transaksi ekonomi. Tidak terlepas juga dalam dunia pendidikan, model pembelajaran tatap muka secara langsung tergantikan dengan model pembelajaran secara daring (dalam jaringan) memanfaatkan smartphone dan internet. Kendala yang dihadapi adalah beberapa mata pelajaran yang diberikan oleh guru kurang dipahami oleh siswa karena hanya berupa teks atau gambar. Selain itu, dengan cara 
belajar membaca teks kurang menarik bagi siswa dan menyebabkan siswa menjadi bosan atau jenuh.

Pelajaran di sekolah dasar yang ada di daerah Jawa Barat salah satunya adalah pelajaran huruf kaganga sunda. Huruf kaganga sendiri merupakan huruf dalam bahasa sunda asli yang perlu dilestarikan sebagai bentuk penghargaan terhadap sejarah dan budaya daerah sunda khususnya. Pembelajaran huruf kaganga sunda ini diupayakan semenarik mungkin untuk membuat siswa asli sunda khusunya mau belajar dan melestarikan budaya asli provinsi Jawa Barat ini.

Augmented reality adalah salah satu perkembangan teknologi dalam bidang perangkat lunak. Augmented Reality banyak digunakan dalam industri game, pendidikan, maupun kedokteran dikarenakan dapat memodelkan suatu objek dalam bentuk 3 Dimensi yang menyerupai objek sebenarnya. Berdasarkan hal tersebut, maka perlu mengkombinasikan teknologi augmented reality dalam bidang pendidikan untuk mengurangi kejenuhan siswa dalam pembelajaran.

\subsection{Rumusan Masalah}

Berdasarkan uraian latar belakang masalah di atas, masalah tersebut dapat dirumuskan sebagai berikut.

1. Bagaimana membuat pembelajaran huruf kaganga sunda menjadi lebih menarik bagi siswa SD?

2. Bagaimana penerapan teknologi augmented reality dalam pembelajaran huruf kaganga sunda?

\subsection{Tujuan Penelitian}

Tujuan yang ingin dicapai dari penelitian ini adalah seperti berikut.

1. Membuat pembelajaran huruf kaganga sunda menjadi lebih menarik dan menyenangkan agar mudah dipelajari siswa.

2. Menerapkan teknologi augmented reality pada pembelajaran huruf kaganga sunda berbasis android. 


\subsection{Landasan Teori}

\section{Augmented Reality}

Augmented Reality atau dalam bahasa Indonesia diterjemahkan menjadi realitas tambahan adalah sebuah teknik yang menggabungkan benda maya dua dimensi maupun tiga dimensi ke dalam sebuah ruang lingkup nyata tiga dimensi lalu memproyeksikan benda-benda maya tersebut dalam waktu nyata (Pamoedji et al., 2017). Augmented Reality (AR) ini berbeda dengan Virtual Reality (VR) yang sepenuhnya menggantikan kenyataan, tapi AR hanya sekedar menambahkan atau melengkapi kenyataan.

Dalam kehidupan sehari-hari AR juga sudah mendominasi pasar dunia, salah satu kegunaan dari AR adalah sebagai sarana dalam berbisnis. Banyak perusahaan yang mulai menggunakan AR sebagai media promosi produk mereka. Hal tersebut merupakan sebuah efisiensi yang sangat unik karen dengan AR para sales tidak harus membawa produk yang besar hanya perlu membawa smartphone dan sebuah brosur untuk di scan di depan calon pembeli. Beberapa teknik yang digunakan dalam augmented reality adalah marker based tracking dan marekerless.

\section{Huruf Kaganga Sunda}

Huruf kaganga sunda merupakan salah satu kebudayaan yang telah berusia cukup lama, secara historis lebih dari 16 abad yang lalu, kebudayaan Sunda memiliki kekayaan peninggalan kebudayaan berupa benda-benda bertulis, seperti prasasti, piagam, serta naskah kuno yang cukup banyak. Hal ini menunjukkan adanya kecakapan tradisi tulismenulis di kalangan masyarakat Sunda. Kenyataan tersebut sekaligus membuktikan adanya kesadaran yang tinggi dari para pendahulu masyarakat Sunda mengenai pentingnya penyampaian informasi hasil ketajaman wawasan, pikiran, dan perasaan mereka berupa gagasan atau ide-ide yang mereka rekam melalui sarana bahasa dan aksara pada setiap kurun waktu yang dilaluinya(Baidillah et al., 2008).

Aksara Sunda Kuno memiliki tipe dasar aksara Pallawa Lanjut. Aksara tersebut memiliki kemiripan dengan model aksara Tibet dan Punjab (band. Holle, 1877), dengan beberapa ciri topologi dari pengaruh model aksara prasasti-prasasti zaman Tarumanagara, sebelum mencapai taraf modifikasi bentuk khasnya. Hal ini nampak sebagaimana yang digunakan dalam prasasti-prasasti dan naskah-naskah Sunda Kuno berbahan lontar dan bambu abad ke-14 hingga abad ke-18 Masehi. 


\section{Unified Modelling Language (UML)}

Unified Modelling Language (UML) adalah sebuah "bahasa" yang telah menjadi standar dalam industri untuk visualisasi, merancang dan mendokumentasikan sistem piranti lunak. UML menawarkan sebuah standar untuk merancang model sebuah sistem. Seperti bahasa-bahasa lainnya, UML mendefinisikan notasi dan syntax/semantik. Notasi UML merupakan sekumpulan bentuk khusus untuk menggambarkan berbagai diagram piranti lunak. Setiap bentuk memiliki makna tertentu, dan UML syntax mendefinisikan bagaimana bentuk-bentuk tersebut dapat dikombinasikan. Notasi UML terutama diturunkan dari 3 notasi yang telah ada sebelumnya: Grady Booch OOD (ObjectOriented Design), Jim Rumbaugh OMT (Object Modeling Technique), dan Ivar Jacobson OOSE (Object-Oriented Software Engineering) (Safaat, 2015).

Jenis-jenis diagram yang ada pada UML yaitu, use case diagram, class diagram, state diagram, sequence diagram, activity diagram, collaboration diagram, component diagram, dan deployment diagram.

\section{Android}

Android adalah sebuah aplikasi open source dan Sistem Operasi berbasis Linux untuk perangkat mobile seperti smartphone dan komputer tablet. Android dikembangkan oleh Open Handset Alliance, dipimpin oleh Google, dan perusahaan lain. Android menawarkan pendekatan terpadu untuk pengembangan aplikasi untuk perangkat seluler yang berarti pengembang hanya perlu mengembangkan untuk Android, dan aplikasi tersebut harus dapat berjalan di perangkat berbeda yang diberdayakan oleh Android. Versi beta pertama dari Android Software Development Kit (SDK) dirilis oleh Google pada tahun 2007 sedangkan versi komersial pertama, Android 1.0, dirilis pada bulan September 2008.

Pada 27 Juni 2012, di konferensi Google I/O, Google mengumumkan versi Android berikutnya, 4.1 Jelly Bean . Jelly Bean adalah pembaruan tambahan, dengan tujuan utama meningkatkan antarmuka pengguna, baik dari segi fungsionalitas maupun kinerja. Kode sumber untuk Android tersedia di bawah lisensi perangkat lunak gratis dan sumber terbuka. Google menerbitkan sebagian besar kode di bawah Lisensi Apache 
versi 2.0 dan sisanya, kernel Linux berubah, di bawah Lisensi Publik Umum GNU versi 2 (Safaat, 2015).

\section{METODE PENELITIAN}

Metodologi penelitian yang digunakan oleh peneliti untuk menyusun laporan ini adalah metode kualitatif dimana pada metode ini penelitian dilakukan secara sistematis, spesifik, terstruktur dan juga terencana dengan baik dari awal hingga mendapatkan sebuah kesimpulan. Penelitian ini difokuskan pada mata pelajaran muatan lokal khususnya siswa kelas 3 sekolah dasar (SD).

Metode pengembangan sistem yang digunakan adalah metode Rappid Application Develepoment (RAD). Rapid Application Development (RAD) merupakan metodologi yang lengkap, dengan 4 fase siklus hidup yang sejajar dengan fase SDLC tradisional, fase dan aktivitas Rapid Application Development (RAD) digambarkan pada pada gambar 1.

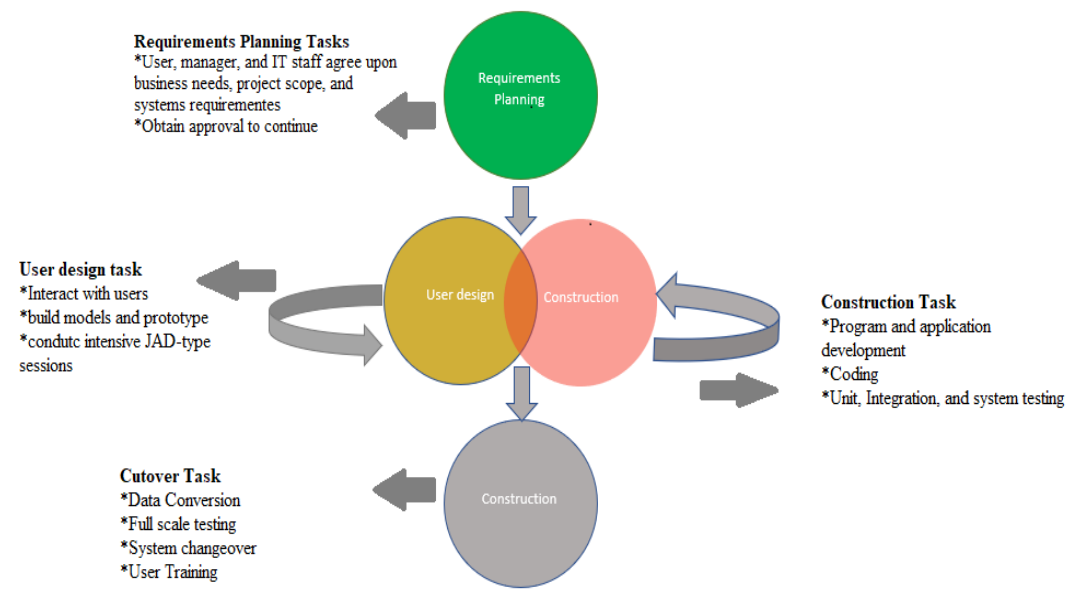

Gambar 1: Model metode RAD

Empat fase dalam Rapid Application Development (RAD) yang dimulai dari analisis kebutuhan pengguna, perancangan, sampai dengan penerapan. Berikut adalah tahapan pengembangan aplikasi dari tiap fase dan aktivitas dalam Rapid Application Development (RAD) (Rosa \& M. Shalahudin, 2014):

1. Requirements Planning Aktivitas pada tahap ini, dilakukan analisis yang dengan cara pertemuan antara pengguna serta analis sistem untuk mengidentifikasikan kebutuhan organisasi/perusahaan serta tujuan dari SI/TI yang akan dibuat. Fokus pada fase ini adalah hasil dari analisa sistem dapat menyelesaikan masalah yang 
terjadi di organisasi/perusahaan. Teknologi informasi dan sistem informasi dapat diarahkan meskipun hanya sebagian dari sistem, fokusnya tetap untuk mengupayakan solusi terhadap permasalahan yang terjadi di perusahaan atau organisasi.

2. User Design Aktivitas User Design adalah tahapan untuk merancang serta memperbaiki sistem sebelumnya. Analis sistem serta pemrogrammer bekerja sama membangun desain sistem informasi yang dikembangkan beserta pola kerja kepada pengguna nantinya. Selama perancangan desain dengan Rapid Application Development (RAD), pengguna melakukan pemeriksaan terhadap prototype yang ada dan Analis sistem akan memperbaiki berdasarkan koreksi dari pengguna.

3. Construction Pada tahap implementasi, analis sistem bekerja sama dengan pengguna dengan cara berkomunikasi terus menerus dan merancang kebutuhan organisasi/perusahaan yang dibutuhkan. Setelah rancangan disetujui maka akan langsung dilakukan pembangunan atau konstruksi terhadap sistem-sistem yang akan dibangun, sistem yang baru dibangun kemudian akan diuji coba setelah itu diperkenalkan kepada perusahaan atau organisasi yang akan menggunakan sistem tersebut.

4. Cutover Merupakan tahapan peralihan, dimana pada aktivitas ini dilakukan perubahan secara langsung antara sistem lama secara langsung digantikan dengan sistem baru termasuk konversi data.

\section{HASIL DAN PEMBAHASAN}

\subsection{Proses Sistem Berjalan}

Hasil pengamatan yang dilakukan oleh penulis para proses belajar mengajar di sekolah dasar masih dilakukan secara konvensional. Maksudnya, guru memberikan file materi kepada siswa baik secara sinkron maupun secara asinkron yang kemudian materi tersebut dipelajari oleh siswa. Proses bisnis dari sistem pembelajaran yang berjalan saat ini diperlihatkan pada gambar 2 di bawah ini. 


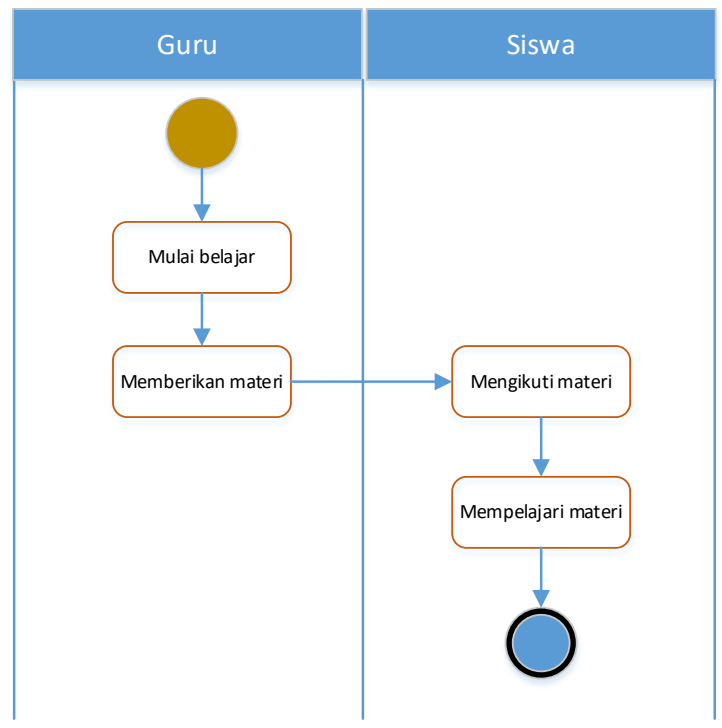

Gambar 2: Proses bisnis pembelajaran siswa

Melihat dari kondisi seperti ini, siswa akan merasa jenuh karena materi yang diberikan berupa teks yang harus dibaca tanpa adanya contoh penulisan secara langsung. Proses bisnis yang diusulkan untuk membuat pembelajaran lebih menarik dengan pemanfaatan teknologi augmented reality ditunjukkan pada gambar 3.

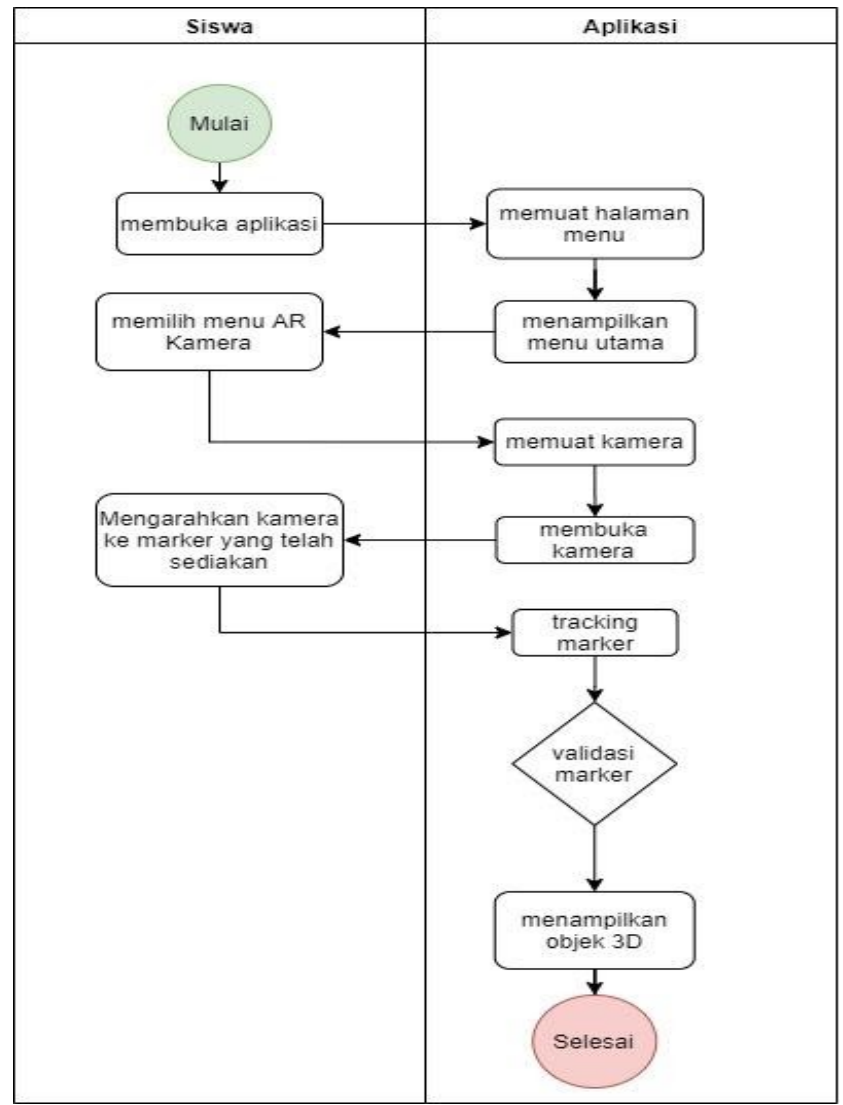

Gambar 3: Proses bisnis diusulkan 


\subsection{Use Case Diagram}

Aplikasi yang akan dikembangkan dalam penelitian ini hanya melibatkan satu aktor yaitu siswa, dimana guru hanya ditekankan pada proses pendampingan dalam pembelajaran. Pendefinisian kebutuhan fungsional dan operasional sistem dari sistem yang akan dibangun disajikan dalam diagram use case pada gambar 4.

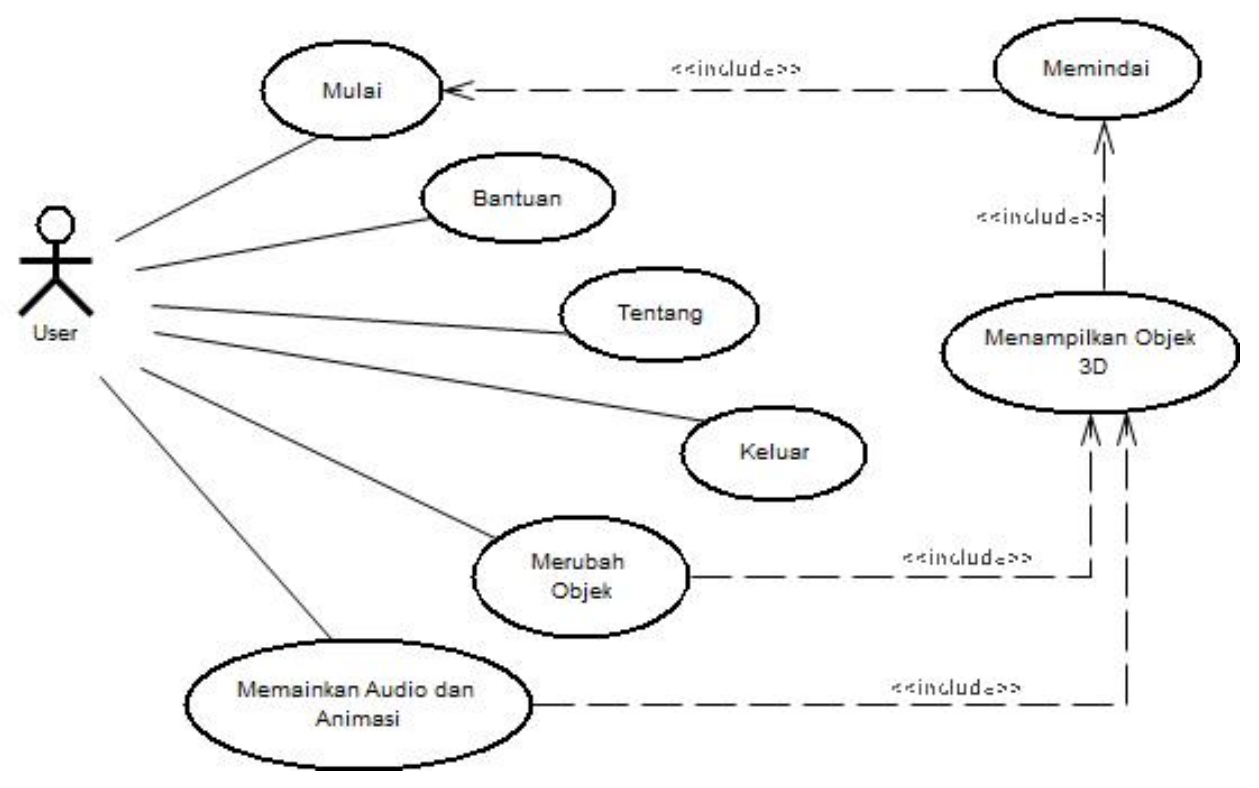

Gambar 4: Use case diagram aplikasi huruf kaganga sunda

\subsection{Perancangan Marker}

Tahapan dalam perancangan bentuk dan isi pada marker yang digunakan serta marker seperti apa yang digunakan dibuat dengan aplikasi AAALogo. Dalam tahapan proses input Augmented Reality (AR) diperlukan sebuah marker dalam tahap proses pengaplikasiannya. Adapun cara dalam pembuatannya adalah dengan membuat sebuah objek persegi empat yang memiliki objek lain di dalamnya baik itu berupa gambar, teks maupun angka dengan warna yang berbeda dengan latar belakang persegi tersebut. Ukuran marker yang digunakan dalam analisis ini adalah 433 x 426 pixel serta gambar yang digunakan berupa file format .jpg, dalam tahap pembuatan marker untuk digunakan oleh aplikasi. 


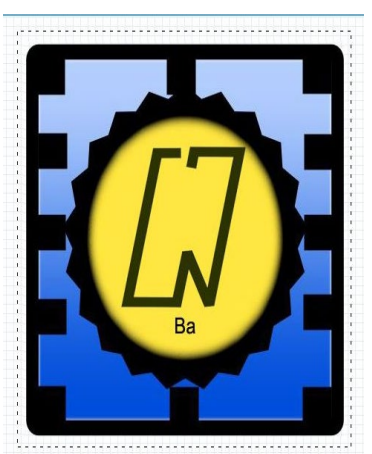

Gambar 5: Marker aplikasi huruf kaganga sunda

\subsection{Implementasi Aplikasi}

Antarmuka (interface) dari aplikasi ini dibuat semenarik mungkin untuk usia anak sekolah dasar dengan nuansa pendidikan dan suatu ciri khas yang menggambarkan simbol dari Provinsi Jawa Barat.

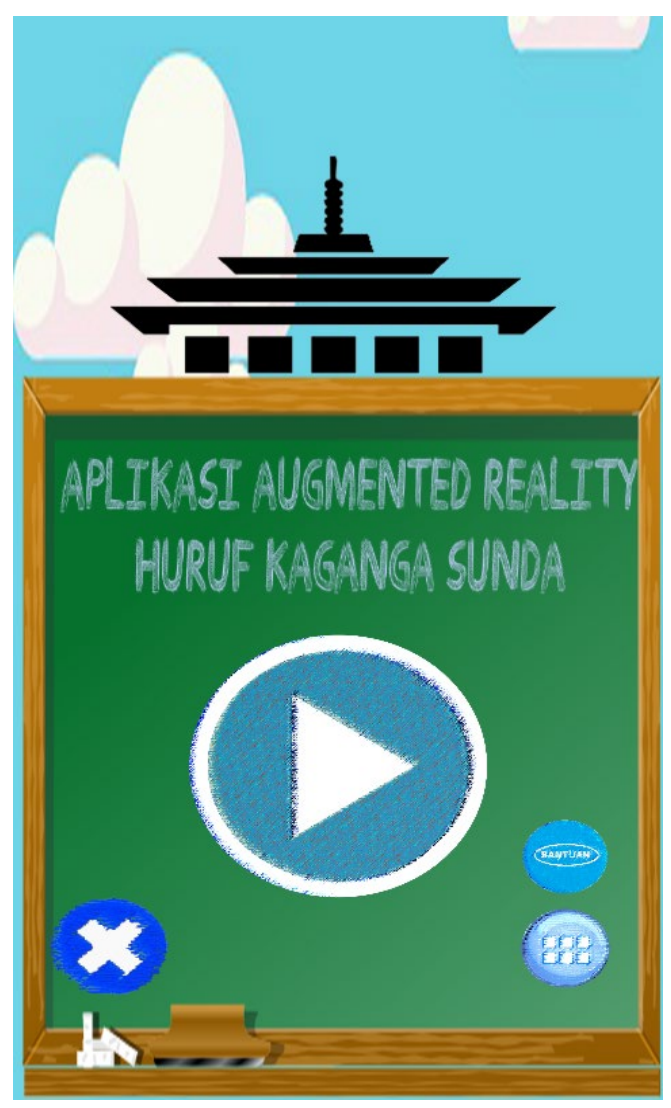

Gambar 6: Halaman awal aplikasi 
Untuk dapat melihat bentuk dari huruf kaganga sunda dalam objek 3 dimensi, pengguna harus terlebih dahulu melakukan pemindaian (scan) marker yang sudah disiapkan melalui aplikasi.

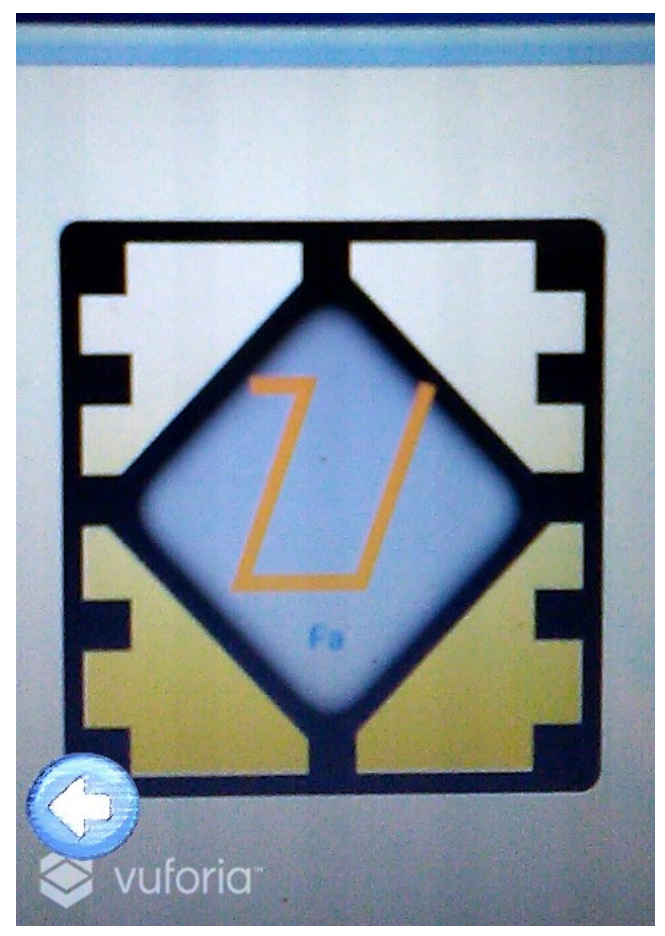

Gambar 7: Halaman AR kamera

Hasil dari pemindaian ini akan menampilkan animasi huruf kaganga dalam objek 3 dimensi. Animasi ini berupa cara penulisan huruf kaganga sunda yang dapat dengan mudah diikuti oleh siswa sekolah dasar. 


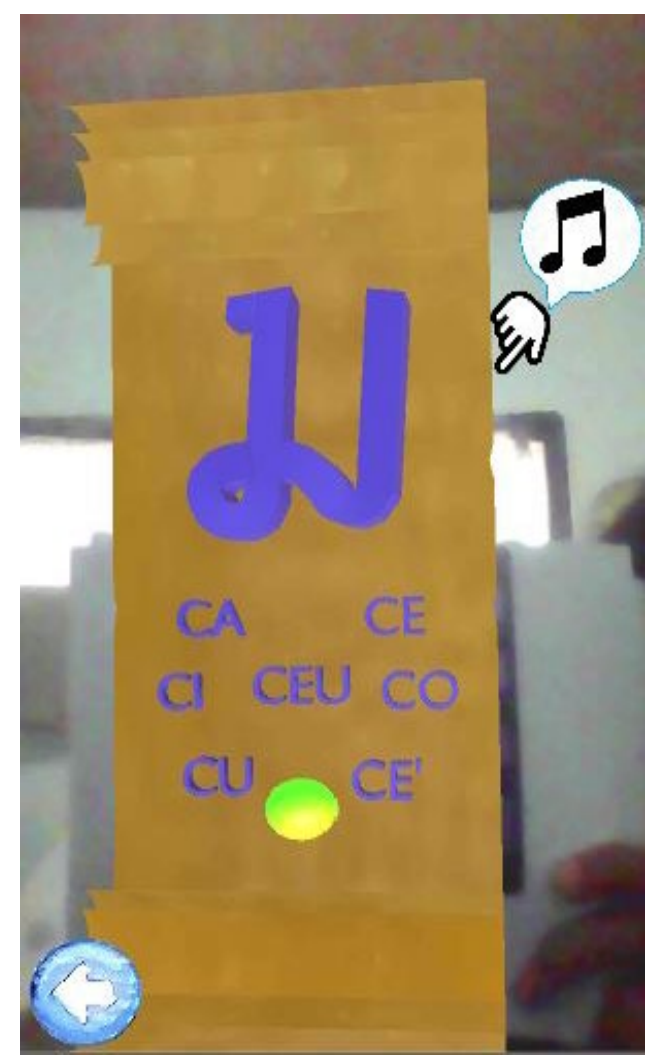

Gambar 8: Hasil pindai AR dalam bentuk 3D

\subsection{Pengujian}

Pengujian bermaksud untuk memeriksa kesesuaian antara sistem dengan requirement. Pengujian ini menggunakan metode black box testing yang berfokus pada persyaratan fungsional perangkat lunak tanpa menguji desain dan program dan menggunakan pengujian Beta dengan target responden adalah guru sekolah dasar dikarenakan adanya wabah covid-19. Pada tahap pengujian black box hanya dilakukan pengujian dengan mengamati eksekusi melalui data uji dan memeriksa fungsional dari perangkat lunak.

Pengujian beta dilakukan dengan memberikan quisioner kepada 60 guru dari 5 Sekolah Dasar yang ada di Kota Bandung dengan skala presentase nilai seperti pada tabel 1 .

Tabel 1: Persentase Interval dan Kategori Penilaian (Sugiyono, 2019)

\begin{tabular}{|c|c|}
\hline Presentase Interval & Kategori \\
\hline $0 \%-19,99 \%$ & Buruk sekali \\
\hline $20 \%-39,99 \%$ & Tidak baik \\
\hline $40 \%-59,99 \%$ & Cukup \\
\hline $60 \%-79,99 \%$ & Baik \\
\hline $80 \%-100 \%$ & Sangat baik \\
\hline
\end{tabular}


Dari hasil quisioner yang telah dibagikan diperoleh tingkat persetujuan terhadap aplikasi yang dibuat $=(82: 100) \times 100 \%=82 \%$. Kesimpulan berdasarkan data yang diperoleh dari 20 responden sesuai dengan tabel 4.3 persentase interval dan kategori penilaian maka data $82 \%$ terletak pada kategori sangat baik.

\section{SIMPULAN}

Simpulan yang dapat diambil dari hasil penelitian yang telah dilakukan adalah seperti berikut.

1. Pembelajaran huruf kaganga sunda dibuat dalam bentuk animasi 3 dimensi yang mengajarkan cara penulisan aksara sunda, sehingga dapat menarik bagi siswa SD.

2. Animasi 3 dimensi huruf kaganga sunda ini ditampilkan menggunakan teknologi augmented reality dalam aplikasi android, sehingga siswa SD dapat belajar sambil bermain.

\section{DAFTAR PUSTAKA}

Baidillah, I., Darsa, U. A., Abdurahman, O., Permadi, T., Gunardi, G., Suherman, A., Ampera, T., Purba, H. S., Nugraha, D. T., \& Sutisna, D. (2008). Direktori Aksra Sunda Untuk Unicode (D. Sutisna (ed.); I). Dinas Pendidikan Provinsi Jawa Barat.

Pamoedji, A. K., Maryuni, \& Sanjaya, R. (2017). Mudah Membuat Game Augmented Reality (AR) dan Virtual Reality (VR) dengan Unity 3D. PT. Elex Media Komputindo.

Rosa, A., \& M. Shalahudin. (2014). Rekayasa Perangkat Lunak: Terstruktur dan berorientasi objek. Informatika.

Safaat, N. (2015). Android: Pemrograman Aplikasi Mobile Smartphone dan Tablet $P C$ Berbasis Android (2nd ed.). Informatika.

Sugiyono. (2019). Metode Penelitian Pendidikan (Kuantitatif, Kualitatif, Kombinasi, $R \& D)$. Alfabeta. 